\title{
Liam O'Callaghan, Rugby in Munster. A Social and Cultural History
}

\section{Laurent Daniel}

\section{(2) OpenEdition}

1 Journals

\section{Édition électronique}

URL : https://journals.openedition.org/etudesirlandaises/10407

DOI : 10.4000/etudesirlandaises. 10407

ISSN : 2259-8863

\section{Éditeur}

Presses universitaires de Caen

\section{Édition imprimée}

Date de publication : 31 décembre 2020

Pagination : 207-208

ISBN : 978-2-84133-996-9

ISSN : 0183-973X

\section{Référence électronique}

Laurent Daniel, "Liam O'Callaghan, Rugby in Munster. A Social and Cultural History », Études irlandaises [En ligne], 45-2 | 2020, mis en ligne le 31 décembre 2020, consulté le 18 novembre 2022. URL : http:// journals.openedition.org/etudesirlandaises/10407; DOI : https://doi.org/10.4000/etudesirlandaises. 10407

\section{(c) (i) (9)}

Creative Commons - Attribution - Pas d'Utilisation Commerciale - Partage dans les Mêmes Conditions 4.0 International - CC BY-NC-SA 4.0

https://creativecommons.org/licenses/by-nc-sa/4.0/ 


\section{Liam O'Callaghan, Rugby in Munster. A Social and Cultural History [2011], Cork, Cork University Press, 2019, 308 p.}

Rugby in Munster. A Social and Cultural History by Liam O'Callaghan was first published in 2011 in the wake of Munster's 2006 and 2008 victories in the Heineken Cup (European cup), only a decade after the advent of professionalisation (1995) forced the Irish Rugby Football Union (IRFU) to reorganise along provincial (1997) rather than the traditional club lines in order to lure Irish players back home and revive its international fortunes whilst ensuring the financial sustainability of the small Irish rugby market in the new era. Even though the province has not been able to reproduce these early victories, the enduring success of neighbouring Leinster on the European rugby scene and the 2014, 2015 and 2018 Six Nation victories of the national team have put rugby in Ireland on a new standing, as the only team sport with a global audience giving Ireland - the whole island for that matter some degree of international sporting exposition and giving O'Callaghan's book a renewed lease of life for both sports historians and social historians of the province.

Originally written as a $\mathrm{PhD}$ thesis, the book is based on extensive use of existing primary material and is firmly set in contemporary sport historiography as made clear throughout the book and made explicit thanks to its organisation into two opening chronological chapters (mainly from the introduction of rugby into Munster in 1870s to the present), followed by five chapters addressing themes familiar to sport historians: class issues; violence and masculinity; politics; commercialisation and professionalism. It follows in the footsteps of Mike Cronin's landmark 1999 reassessment of the birth and development of the Gaelic Athletic Association (GAA) within the context of the $19^{\text {th }}$-century British sports revolution (Sport and nationalism in Ireland, Dublin, Four Courts Press, 1999) rather than as a purely and exclusively political organisation. As one of a burgeoning generation of Irish sports historians reassessing sports in post-nationalist Ireland (together with Paul Rouse and Tom Hunt, among others), O'Callaghan gives a much more complex picture of this game than the widespread characterisations which had thus far been available.

Indeed, imported into Trinity College in the 1850s and then into Munster by aristocrats who had been educated at elite English institutions, rugby has traditionally been described as a middle-class, "foreign" and imperial game.

O'Callaghan concedes that: “The generalization which sees rugby in Ireland as a homogenously middle-class pursuit save for a degree of proletarian infiltration in Limerick, is broadly true" (p. 65). However, the Limerick exception proves that sport is the product of the social and economic context in which it evolves. Whereas in Cork, rugby was and is mainly played by members of the professions living in the wealthy suburbs of the city, as a means of mixing with those of similar socio-economic background, in Limerick, where the social base was narrower, an improbable trio of men of widely different education, ethos and political inclinations sharing a common interest in sport and the condition of the working classes established and supervised a series of tournaments on Sundays 
(which the Catholic Church did not object to). This gave the male members of the working classes of the city an unprecedented and unequalled opportunity to play sport, develop masculine and parish identity and eventually articulate and mediate strong inner-city rivalries. As it was also used as a recruitment pool by senior rugby clubs of the city, Limerick developed a very specific rugby culture characterised by competitiveness and toughness which was unique in Ireland but could also be observed in Northern England and France.

Regarding its so-called “foreign” nature, O'Callaghan provides a wealth of evidence showing that the transformation of folk football into various specific sports codes was a gradual process, and that in the late $19^{\text {th }}$ century there were frequent overlaps and great fluidity between "native" and "foreign" games. For some of its devotees of the period, rugby was as valid a medium for expressing nationalistic sentiment as the GAA. The totemic GAA ban on "foreign" games was originally meant as a means of boosting interest in the Gaelic sport's association and attained extreme ideological importance only in the decades after independence: "attachment of politico-cultural significance to different sports in Ireland was an evolutionary, contested process, the success of which was both regionally and chronologically varied" (p. 143).

Thirdly, as a product of the Victorian public-school system, rugby theoretically served the function of educating the ideal imperial man and providing a model for moral gentlemanliness. However, O'Callaghan goes at great lengths to show that rugby in Limerick was and is much more competitive than the original amateur ideal would have allowed and that the manliness it was devised to engender took on a very different shape in Munster, where both players and spectators gave short shrift to the self-discipline the game is supposed to nurture. There again: "Manhood ideologies are not immutable constructs but are adaptations to social environments which are part of the material conditions of life in the various societies during particular time periods" (cited p. 118).

Therefore, likewise, the $21^{\text {st }}$ century characterisation of Munster rugby as a unique phenomenon built upon notions of community solidarity and humble social roots is only partially true if not entirely false. It was crafted by early $21^{\text {st }}$ century marketers to create some sense of belonging and uniqueness and ensure its success.

Still plenty more work to do by (sports) historians.

Laurent DANIEL

\section{Reading Brendan Behan, John McCourt (dir.), Cork, Cork University Press, 2019, $\mathrm{x}+250 \mathrm{p}$.}

L'ouvrage de John McCourt, Reading Brendan Behan, ne peut qu'être salué avec enthousiasme car il constitue une nouvelle, très attendue, contribution sur l'œuvre de l'un des auteurs irlandais les plus éclectiques, mais aussi l'un des moins étudiés. 